\title{
POSSIBILITIES FOR THE USE OF GOAT MEAT IN THE PRODUCTION OF TRADITIONAL SUCUK
}

\author{
S. Stajić $\hat{c}^{1}$ N. Stanišić ${ }^{2}$, M. Perunović ${ }^{1}$, D. Živković ${ }^{1}$, M. Žujović ${ }^{2}$ \\ ${ }^{1}$ Department of Food Technology and Biochemistry, Faculty of Agriculture, University of Belgrade, \\ Nemanjina 6, 11080 Belgrade, Republic of Serbia \\ ${ }^{2}$ Institute for Animal Husbandry, Autoput 16, P. Box 23, 11080, Belgrade-Zemun, Republic of Serbia \\ Corresponding author: stajic@agrif.bg.ac.rs \\ Original scientific paper
}

\begin{abstract}
Two variants of sucuk were made: one of beef meat and beef tail fat and another of goat meat and goat tail fat with meat/fat ratio of 75/25 and the same ingredients. After filling, the sausages were hung to dry in a traditional smoking house (without the possibility to control the temperature or humidity). Weight loss, $\mathrm{pH}$, non-protein nitrogen content, basic chemical composition, instrumental colour measurement and sensory evaluation were done for both variants. Both variants had an almost identical weight loss (36.98 beef sucuk and 36.25 goat sucuk). Changes in $\mathrm{pH}$ value and non-protein nitrogen content had the same tendency and end values did not differ. The basic chemical composition at the end of production indicates that both variants were of very good quality. L* and b* values did not differ, but there was a significant difference in a* value $(11.72$ beef and 14.15 goat). In terms of appearance, texture and taste, assessors gave poorer grades to goat sucuk, but these grades do not indicate that the product is unacceptable (they were more than 5). It is possible to replace goat tail fat with beef fat to appease the specific flavour of the product and to make it more acceptable to consumers who may not be used to such flavour.
\end{abstract}

Key words: sucuk, goat meat, instrumental colour, sensory evaluation

\section{Introduction}

Fermented sausages have been produced for quite a long time and there are various types of these sausages. Fermented sausages are defined as ground meat mixed with salt and curing agents, stuffed into casings and subjected to a fermentation process in which microorganisms play a crucial role (Lücke, 1994). Lactic acid occurs as a product of fermentation; it lowers the $\mathrm{pH}$ value of the product and helps to create the colour, taste and texture of the product (Cenci-Goga et al., 2008). Fermentation is followed by ripening during which a number complex reactions take place, whose outcome is the degradation of proteins, lipids and 
carbohydrates, as a result of the activity of endogenous muscle enzymes and microbial enzyme (Spaziani et al., 2009).

Sucuk is a Turkish-style dry fermented sausage, very popular in Turkey and a number of Middle East countries, as well as Europe (Ercoskun and Özkal, 2011). As for Serbia, it is traditionally produced in the western mountainous regions, primarily in small plants or village households in autumn and winter when weather conditions (temperature and relative humidity) are favourable. Small pieces of beef meat leftovers from dry beef (traditional dry meat product) production and tail fat are used. Meat/tail fat ratio is around 80:20; they are ground (about $4-5 \mathrm{~mm}$ ) and mixed with salt and spices. The mixture is usually added 2.0 $2.5 \%$ of salt. Spices used include powdered black pepper, fresh garlic and red paprika, though local recipes may vary. The mixture is stuffed into beef small intestine and tied with rope. The product is then smoked and dried for over thirty days under local weather conditions. The sensory characteristics of sucuk are the following: very dark red colour, flavour and odour are of spicy fermented beef meat, with mild smoke aroma; the texture is very specific due to the addition of beef fat.

As for goat meat, there is great interest in kid meat and during the past decades, due to its high biological value, demand for this meat has increased even in countries with a high standard of living (Žujović et al., 2009). Over the past few years in Serbia, interest for goat breeding has been increasing, especially in some regions (Memiši et al., 2009). Goat meat has a specific and strong aroma, and the meat of older animals has poor structure. However, goat meat can be very successfully used in the fermented sausage processing (Cosenza et al., 2003; Nassu et al., 2002).

The aim of this study was to investigate the possibility of using goat meat in sucuk processing and also to describe their chemical and sensory quality characteristics.

\section{Materials and Methods}

Two variants of sucuk were made in a small processing plant of the Institute for Animal Husbandry (Belgrade) in the period January-February 2010: of beef meat (about 8\% fat) and beef tail fat (Variant B), and of goat meat (about $8 \%$ fat) and goat tail fat (Variant $G$ ) in the ratio of $75 / 25$. Both variants were added the same amounts of the following ingredients: $2.3 \%$ curing salt $(\mathrm{NaCl}$ with $0.6 \%$ of $\mathrm{NaNO}_{2}$ ), $0.35 \%$ sucrose and $0.5 \%$ spice mixture (powdered black pepper, garlic and red paprika). Meat and tail fat were first frozen to $-4{ }^{\circ} \mathrm{C}$ and then minced in a meat grinder (Seydelman 114, Germany) to about $1 \mathrm{~cm}$. Cutting and mixing with ingredients was carried out in the cutter (Seydelman K60, Germany) to $5 \mathrm{~mm}$ particle size. The mixture was filled in beef small intestine of $38 \mathrm{~mm}$. Sausages 
were tied with rope and made into horseshoe shape. After stuffing, the sausages were hung to dry in a traditional smoking house (without the possibility to control the temperature or humidity), with the parameters varying between $10-15{ }^{\circ} \mathrm{C}$ and relative humidity $(\mathrm{RH}) 75-90 \%$. They were then occasionally smoked.

Three sausages were taken from each group for all analyses. Sampling was carried out on production days $0,1,3,7,14,21$ and 30 to determine $\mathrm{pH}$ value, nonprotein nitrogen (NPN) and weight loss. Chemical analysis was conducted at the beginning (day 0) and end (day 30) of production. Sausage colour was determined at the end of production, and sensory evaluation was carried out.

Six individual sausages were weighed on the scales (Chyo MK-2000B), with a $0.1 \mathrm{~g}$ precision ratio, in order to determine weight loss. USA).

$\mathrm{pH}$ value was measured by $\mathrm{pH}$-meter Hanna, HI 83141 (Hanna Instruments

NPN content (mg/100g dry matter (DM)) was determined according to the method of Hughes et al. (2002).

The chemical composition of meat was determined in the following manner: moisture by drying samples at $105{ }^{\circ} \mathrm{C}$ (ISO 1442, 1997); protein content by Kjeldahl method and multiplying by factor 6.25 (ISO 937, 1978); fat content by Soxhlet method (ISO 1443, 1973), and ash content by sample mineralization at $550-600{ }^{\circ} \mathrm{C}$ (ISO 936, 1998).

Sausage colour was determined by Chromameter CR-400 (Minolta Co. Ltd, Tokyo, Japan), in line with the CIE $\mathrm{L}^{*} \mathrm{a}^{*} \mathrm{~b}^{*}$ system ( $\mathrm{L}^{*}$ - lightness, $\mathrm{a}^{*}$ - red colour share, $b^{*}$ - yellow colour share). The colour of the cross section at three fresh cuts was measured.

The evaluation of sensory characteristics of sausages was conducted by nine assessors with previous experience in the evaluation of dried fermented sausages. A numeric-descriptive scale with nine-point system was used to evaluate of appearance, cut appearance, colour, odour, texture and taste of sausages $(1$ - extremely unacceptable, 9 - extremely acceptable).

The results were processed by single-factor analysis of variance (ANOVA). The differences between individual averages were tested using Tukey's method. Significant differences were considered for $\mathrm{P}<0.05$. Calculations were done with software Statistica 6.0 PL, for Windows (Statsoft inc.)

\section{Results and Discussion}

Weight loss was almost identical in both variants (Figure 1) and no statistically significant difference was observed. More intensive weight loss was recorded in both variants between days 7 and 14, and especially after day 14, when the achieved $\mathrm{pH}$ value was close to $\mathrm{pI}$ (Figure 2), which accelerates drying.

Initial $\mathrm{pH}$ values differ, the lower being in B variant, which is not unusual. Similar results were reported by Soyer et al. (2005) and Soyer and Ertas (2007) for beef 
sucuk and Nassu et al. (2002) for goat fermented sausages. Intensive pH drop started on day 3 in both variants, because of production conditions resembling traditional ones. The drop of $\mathrm{pH}$ value in traditional dry sausages is slight and fermentation is long because of low temperatures. $\mathrm{pH}$ value close to $\mathrm{pI}$ was achieved around day 14, corresponding to weight loss which is more intensive from this day onwards.

$\mathrm{pH}$ value at the end of production was alike and stood at 5.13 (B) and 5.21 (G). Bozkurt and Bayram (2006) cited Turkish Standard Institute (TSI) that $\mathrm{pH}$ value of sucuk of good quality should be in the range of 4.7-5.2.

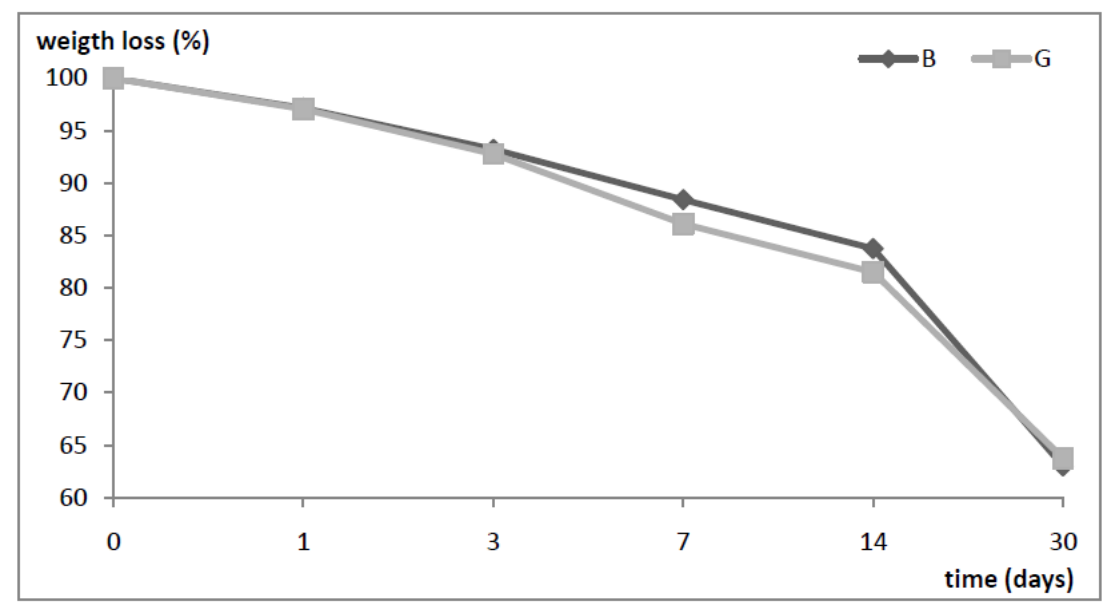

Figure 1. Weight loss of sucuks

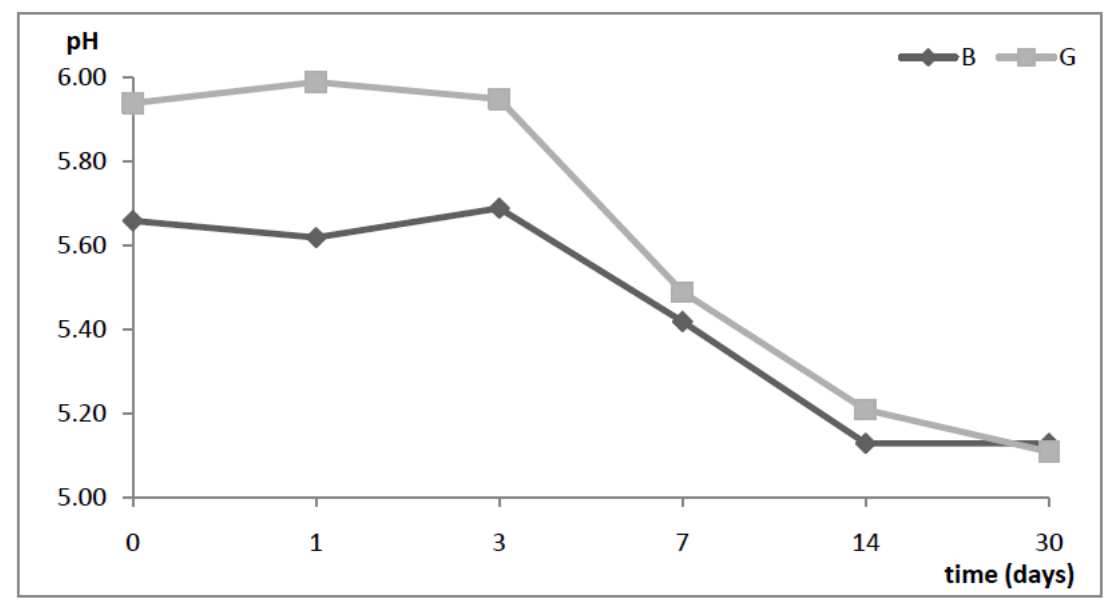

Figure 2. pH value changes during production 
Table 1. Chemical composition of sucuk (\%)

\begin{tabular}{|l|c|c|c|c|c|}
\hline & & Moisture & Fat & Ash & Proteins \\
\hline \multirow{2}{*}{ Day 0 } & B & $56.06 \pm 0.77$ & $24.45 \pm 0.50$ & $3.07 \pm 0.12$ & $16.21 \pm 0.53$ \\
\cline { 2 - 6 } & G & $57.39 \pm 0.78$ & $23.19 \pm 0.37$ & $3.02 \pm 0.02$ & $16.16 \pm 0.82$ \\
\hline \multirow{2}{*}{ Day 30 } & B & $32.39 \pm 0.26$ & $36.90 \pm 0.95$ & $5.03 \pm 0.15$ & $24.19 \pm 1.43$ \\
\cline { 2 - 6 } & G & $33.03 \pm 0.12$ & $36.61 \pm 0.63$ & $5.09 \pm 0.14$ & $25.10 \pm 0.61$ \\
\hline
\end{tabular}

The chemical composition of sucuk (Table 1) at the start of production was very similar and indicated careful selection of raw material in order to get balanced product content. The chemical composition at the end of production did not differ. Both variants of sucuk meet quality requirements envisaged by national regulations and contain less than $35 \%$ of moisture and more than $16 \%$ of meat proteins.

Changes in the NPN content (Figure 3) indicate protein degradation and the generation of low molecular weight peptides and free amino acids; they affect the generation of compounds, which in turn affect the $\mathrm{pH}$ value, taste and flavour in dry and semi-dry sausages (Martín-Sánchez et al., 2011). The pattern of changes in the NPN content correspond to drop of $\mathrm{pH}$ value and increase more intensively after day 3. The $\mathrm{pH}$ value decline activates muscle proteinases, and also indicates the development of microflora, whose activity further affect proteolysis (Spaziani et al., 2009). At the end of production, an increase of $30.76 \%$ (B) and 41.23 (G) were recorded, in agreement with authors cited by Fanco et al. (2002), who reported a rise of $50 \%$ and less.

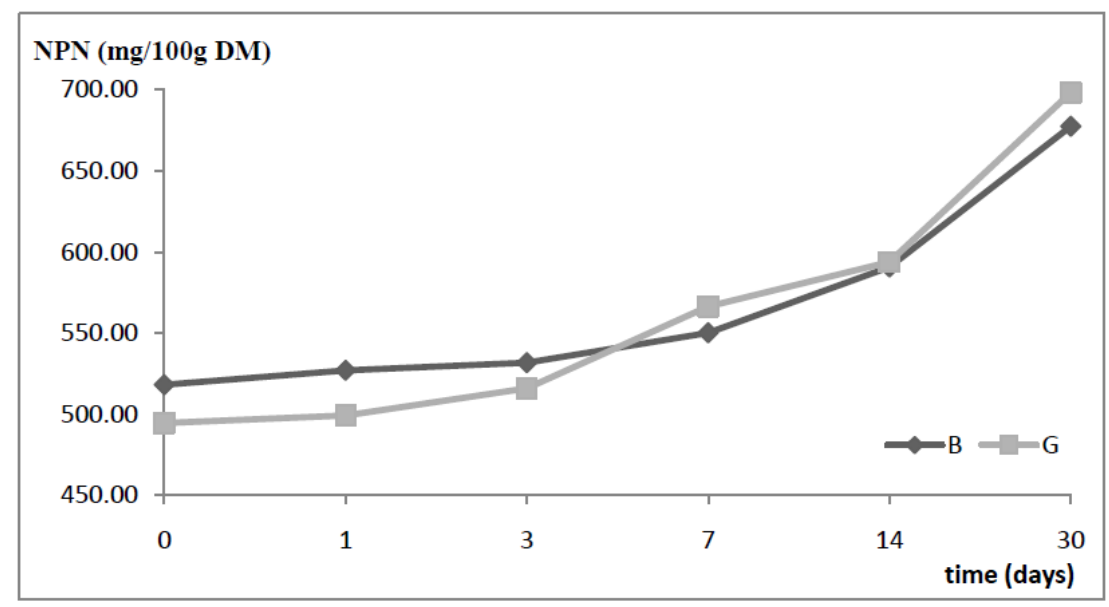

Figure 3. NPN changes during production 


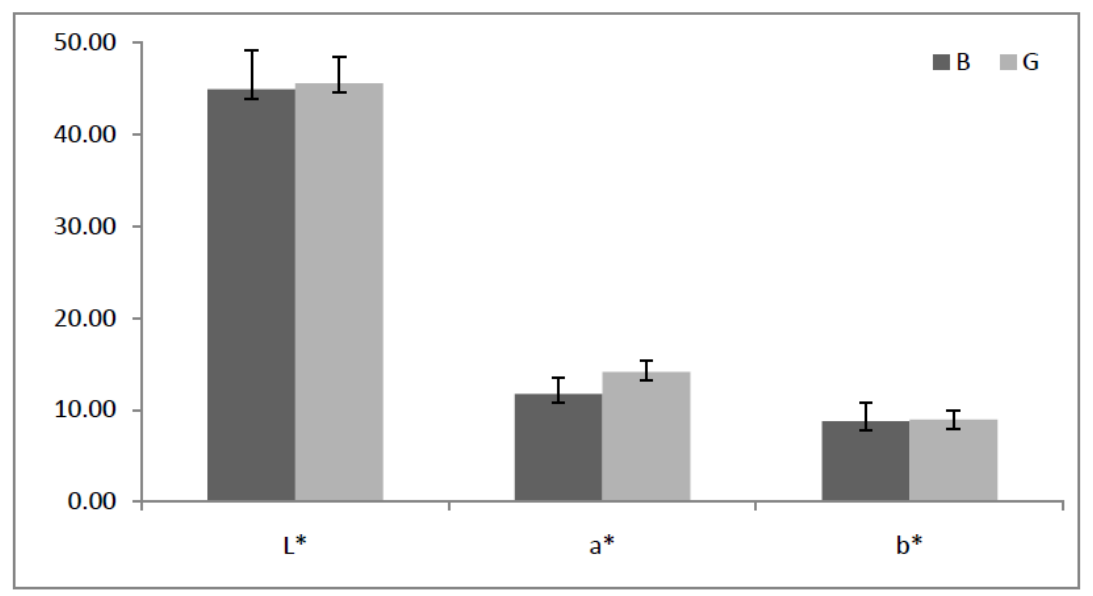

Figure 4. Colour evaluation

Insrumental colour measurement showed that there were no differences in $\mathrm{L}^{*}$ and $\mathrm{b}^{*}$ values, but that $\mathrm{a}^{*}$ values statistically differed (Figure 4). Lower $\mathrm{a}^{*}$ value in variant $\mathrm{G}(11.72)$ indicates that it was less bright red compared with goat meat variants (14.15). Uren and Babayidit (1997) reported for sausages obtained from various meat plants in Turkey and found that $\mathrm{L}^{*}$ values were between 35.87 and 45.92, redness between 6.87 and 14.14 and and yellownes between 10.04 and 17.62 .

Assessors did not find any statistically relevant differences between these two variants in terms of cut appearance, colour and odour (Figure 5). On the other hand, $G$ sucuk received poorer grades in terms of appearance, texture and taste. Texture and taste are parameters that received the lowest grades in variant G (5.29 and 5.43), but these grades do not indicate that the product is unacceptable, as they are in the upper half of the grading scale (1-9). As goat meat and especially fatty tissue have specific taste, it is possible that they affected the lower grades. Acceptable taste can be achieved by substituting goat fatty tisue with that of beef, which, being more common, is more acceptable for the majority of consumers. 


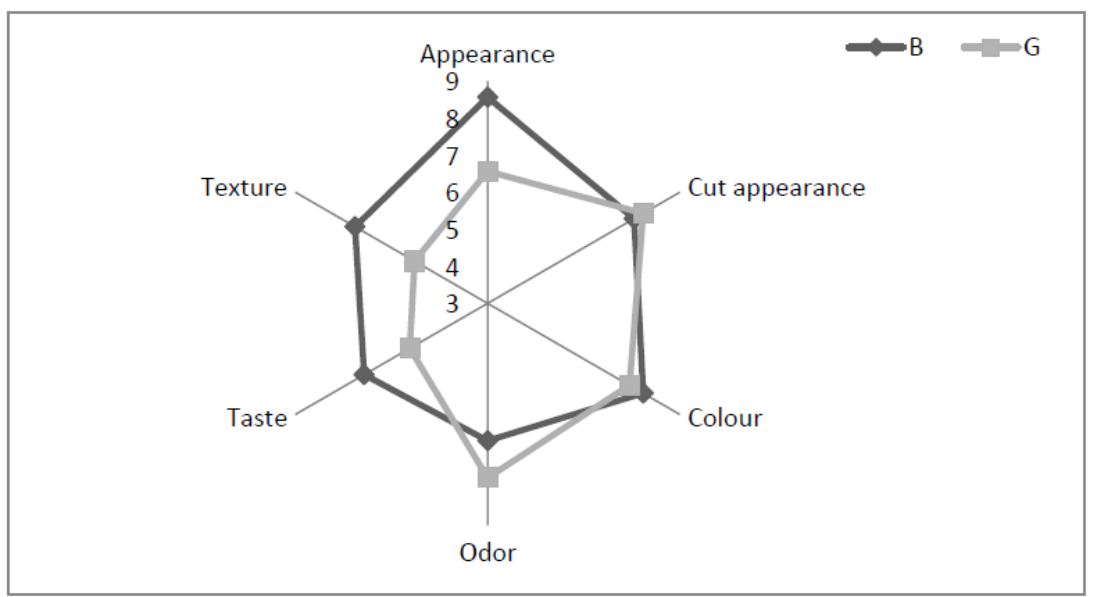

Figure 5. Sensory evaluation of sucuk

\section{Conclusion}

Research has shown that goat meat with goat fatty tissue may be used for the produciton of sucuk. There are no significant differences in terms of observed physical-chemical aprameters between the two variants at the end of production. Greater lightness $\left(\mathrm{L}^{*}\right)$ indicates that the goat variant is more bright red compared with the beef variant, but sensory evaluation does not point to any significant difference in terms of colour. Because of the specific flavour of goat meat and fatty tissue, this variant of sucuk received poorer sensory evaluation grades in appearance, texture and taste. It is possible to replace sheep and goat tail fat with beef fat to appease the specific flavour of the product and to make it more acceptable to consumers who may not be used to such flavour.

\section{Mogućnost upotrebe kozjeg mesa u proizvodnji tradicionalnog sudžuka}

S. Stajić, N. Stanišić, M. Perunović, D. Živković, M. Žujović

\section{Rezime}

U Srbiji, sudžuk se tradicionalno proizvodi u planinskom delu, uglavnom u malim pogonima ili domaćinstvima, u jesenjem i zimskom periodu, kada to klimatski uslovi (temperatura i relativna vlažnost) dozvoljavaju. 
U ovom ogledu napravljene su dve varijante sudžuka: prva od goveđeg mesa i masnog tkiva sa repa goveda i druga od kozjeg mesa i masnog tkiva sa repa koza. Kod obe grupe kobasica je odnos meso/masno tkivo bio 75/25 i korišćeni su isti začini i aditivi. Nakon punjenja, kobasice su sušene u tradicionalnoj pušnici. Kod obe varijante kobasica određen je: gubitak mase tokom sušenja, $\mathrm{pH}$, neproteinski azot, osnovni hemijski sastav i izvršeno je instrumentalno merenje boje i senzorska ocena.

Obe grupe kobasice su imale skoro identičan gubitak mase tokom sušenja (36,98 kod goveđeg i 36,25 kod kozjeg sudžuka). Promene pH vrednosti i neproteinskog azota tokom zrenja su imale istu tendenciju i njihove krajnje vrednosti se nisu značajno razlikovale. Na osnovu podataka za osnovni hemijski sastav na kraju procesa proizvodnje, zaključeno je da su obe grupe kobasica bile veoma dobrog kvaliteta. $L^{*} \mathrm{i} \mathrm{b}^{*}$ vrednosti se nisu značajno razlikovale, dok je statistički značajna razlika između grupa utvrđena za vrednost a* $(11,72 \mathrm{kod}$ goveđih i 14,15 kod kozjih kobasica). U pogledu senzornih karakteristika: spoljnog izgleda, teksture i ukusa, kozji sudžuk je ocenjen nešto slabije, međutim, takav proizvod je i dalje bio veoma prihvatljiv (sve ocene su bile iznad 5).

Jedan od načina da se smanji specifična aroma sudžuka napravljenog od kozjeg mesa, što bi ga učinilo prihvatlivijim za širu grupu potrošača, jeste zamena kozjeg loja sa goveđim.

\section{References}

BOZKURT H., BAYRAM M. (2006): Colour and textural attributes of sucuk during ripening. Meat Science, 73, 2, 344-350.

CENCI-GOGA B.T., RANUCCI D., MIRAGLIA D., CIOFFI A. (2008): Use of starter cultures of dairy origin in the production of Salame nostrano, an Italian drycured sausage. Meat Science, 78, 4, 381-390.

COSENZA G.H., WILLIAMS S.K., JOHNSON D.D., SIMS C., MCGOWAN C.H. (2003): Development and evaluation of a cabrito smoked sausage product. Meat Science, 64, 2, 119-124.

ERCOSKUN H., ÖZKAL S.G. (2011): Kinetics of traditional Turkish sausage quality aspects during fermentation. Food Control, 22, 2, 165-172.

FANCO I., PRIETO B., CRUZ J.M., LÓPEZ M., CARBALLO J. (2002): Study of the biochemical changes during the processing of Androlla, a Spanish dry-cured pork sausage. Food Chemistry, 78, 3, 339-345.

HUGHES M.C., KERRY J.P., ARENDT E.K., KENNEALLY P.M., MCSWEENEY P.L.H., O'NEILL E. E. (2002): Characterization of proteolysis during the ripening of semi-dry fermented sausages. Meat Science, 62, 2, 205-216. LÜCKE F.-K. (1994): Fermented meat products. Food Research International, 27, 3, 299-307. 
MARTÍN-SÁNCHEZ A.M., CHAVES-LÓPEZ C., SENDRA E., SAYAS E., FENÁNDEZ-LÓPEZ J., PÉREZ-ÁLVAREZ J.Á. (2011): Lipolysis, proteolysis and sensory characteristics of a Spanish fermented dry-cured meat product (salchichón) with oregano essential oil used as surface mold inhibitor. Meat Science, 89, 1, 35-44.

MEMIŠI N., ŽUJOVIĆ M., TOMIĆ Z., PETROVIĆ P.M. (2009): Slaughter results for kids of the domestic balkan goat. Biotechnology in Animal Husbandry, 25, 1-2, 125-132.

NASSU R.T., GONCALVES L.A.G., BESERRA F.J. (2002): Effect of fat level in chemical and sensory characteristics of goat meat fermented sausage. Pesquisa Agropecuaria Brasileira, 37, 8, 1169-1173.

SOYER A., ERTAS A.H. (2007): Effects of fat level and storage time on lipid and color stability of naturally fermented Turkish sausages (sucuk). Journal of Muscle Foods, 18, 3, 330-340.

SOYER A., ERTAS A.H., ÜZÜMCÜOGLU Ü. (2005): Effect of processing conditions on the quality of naturally fermented Turkish sausages (sucuks). Meat Science, 69, 1, 135-141.

SPAZIANI M., DEL TORRE M., STECCHINI M.L. (2009): Changes of physicochemical, microbiological, and textural properties during ripening of Italian low-acid sausages: proteolysis, sensory and volatile profiles. Meat Science, 81, 1, 77-85.

ÜREN A., BABAYIGIT D. (1997): Colour parameters of Turkish-type fermented sausage during fermentation and ripening. Meat Science, 45, 4, 539-549.

ŽUJOVIĆ M., STANIŠIĆ N., MEMIŠI N. (2009): Autochthonous balkan goat breed - composition and traits of kid carcass. Biotechnology in Animal Husbandry, $25,5-6,411-420$. 